\title{
Jaminan Kepastian Hukum Atas Pinjaman Modal Terhadap Kegiatan Usaha Rumah Tangga Berdasarkan Undang-Undang Republik Indonesia Nomor 10 Tahun 1998 Tentang Perubahan Atas Undang-Undang Nomor 7 Tahun 1992 Tentang Perbankan \\ (STUDI DI PT. BANKALTIMTARA CABANG SAMARINDA)
}

\author{
Namira Meidina Aulia, dan Parlindungan Pasaribu \\ Mianamira60@yahoo.co.id,parlindunganpasaribu_uwgm@yahoo.com \\ Alumni dan Dosen Fakultas Hukum \\ Universitas Widya Gama Mahakam Samarinda
}

\begin{abstract}
ABSTRAK
Penelitian ini bertujuan untuk mengetahui Bentuk Jaminan Kepastian Hukum terhadap Pemberian Pinjaman Modal Kegiatan Usaha Rumah Tangga ditinjau dari Undang-Undang Nomor 10 Tahun 1998 Tentang Perubahan atas Undang-Undang Nomor 7 tahun 1992 Tentang Perbankan dan Kendala dalam Proses Pinjaman Modal oleh Pelaku Usaha Rumah Tangga di Perbankan. Penelitian ini merupakan penelitian hukum Normatif yang bersumber dari bahan hukum primer dan bahan hukum sekunder. Hasil penelitian menunjukkan bahwa Bentuk Jaminan Kepastian Hukum terhadap Pemberian Pinjaman Modal Kegiatan Usaha Rumah Tangga yakni adapun Bentuk Jaminannya yakni dalam Bentuk Jaminan Berwujud, Bentuk Jaminan Tidak Berwujud, Bentuk Jaminan Benda Bergerak, Bentuk Jaminan Benda Tetap / Tidak Bergerak. Dan Adapun bentuk kepastian hukum terhadap pemberian pinjaman modal kegiatan usaha rumah tangga yakni dalam bentuk tertulis yang tertuang didalam Surat Perjanjian Pinjam Uang (SPPU). Kemudian terhadap Kendala dalam Proses Pinjaman Modal oleh Pelaku Usaha Rumah Tangga di Perbankan yakni Data Tidak Lengkap dan Valid, Prosedur pengajuan pinjaman modal usaha ke bank seringkali memakan waktu, prosesnya berbelit-belit dan syaratnya tidak mudah terpenuhi, Usaha Dianggap Kurang Produktif, Tidak adanya Agunan/Jaminan Tambahan, Legalitas Usaha yang dianggap buruk, Riwayat Kredit Buruk. Sehingga disarankan kedepannya pihak perbankan dapat lebih mempermudah calon debitur dalam mengajukan pinjaman modal usaha rumah tangga, walaupun bank menerapkan prinsip kehati-hatian dengan mewajibkan adanya agunan untuk menjamin kepastian hukumnya, akan tetapi pihak bank juga diharapkan tidak berpatokan pada aspek agunan saja tetapi bank juga perlu mempertimbangkan aspek lainnya.
\end{abstract}

Kata Kunci : Jaminan, Kepastian Hukum, Usaha Rumah Tangga 


\begin{abstract}
This study aims to find out the form of Legal Assurance Guarantee on Capital Lending of Household Business Activity in terms of Law Number 10 the year 1998 Concerning Amendment to Law Number 7 of 1992 Concerning Banking and Constraints in Capital Lending Process by Household Business Actor in Banking. This research is normative law research that comes from primary law material and secondary law material. The result of the research shows that the form of Assurance of Legal Certainty to the Capital Lending of Household Business Activity, namely Forms of Guarantee that is in Tangible Assurance Form, Intangible Assurance Form, Form of Guaranteed Movement, Form of Assurance of Permanent / Unmoving Equipment. And the form of legal certainty to the lending of the capital of household business activity that is in the written form contained in the Letter of Credit Agreement (SPPU). Then to the Constraints in Capital Loan Processing by Household Business Actors in Banking namely Incomplete and Valid Data, Procedure of business loan to bank is often time-consuming, the process is complicated and the conditions are not easily fulfilled, Business Considered Less Productive, Absence of Collateral / Additional Guarantees, Bad Business Legality, Bad Credit History. Therefore, it is suggested that in the future, the bank can further facilitate the debtor in applying for the household capital loan, although the bank applies the prudential principle by requiring the collateral to guarantee its legal certainty, the bank is also expected not based on the collateral aspect but also the bank consider other aspects.
\end{abstract}

Key words: Guarantee, Legal Certainty, Household Business.

\title{
PENDAHULUAN
}

\section{A. Latar Belakang}

Dalam rangka meningkatkan taraf hidup masyarakat, bangsa Indonesia telah melakukan pembangunan untuk mewujudkan tujuan nasional, yaitu mewujudkan masyarat yang adil dan makmur secara materiil dan spiritual berdasarkan Pancasila dan Undang-undang Dasar 1945. Guna mewujudkan tujuan nasional tersebut diperlukan usaha untuk meningkatkan pelaksanaan pembangunan yang terpadu dan berkesinambungan antar bidang. Pemerintah Indonesia telah melakukan berbagai usaha untuk lebih memperhatikan keserasian, keselarasan, dan keseimbangan dalam rangka mewujudkan masyarakat yang adil dan makmur. Usaha yang telah dilakukan pemerintah tersebut salah satunya adalah dengan meningkatkan dan menyempurnakan dalam bidang hukum dalam rangka pembinaan dan pembaharuan hukum nasional.
Usaha pemerintah tersebut bertujuan untuk memajukan pembangunan yang telah dicapai agar lebih mantap dan mengarah pada sasarannya sehingga masyarakat dapat memperoleh kepastian hukum demi terwujudnya keadilan di Indonesia. Di dalam Undang-Undang Dasar Tahun 1945, Pasal 28 D ayat (1) menyebutkan bahwa, "Setiap orang berhak atas pengakuan, jaminan, perlindungan, dan kepastian hukum yang adil serta perlakuan yang sama dihadapan umum". Ini merupakan pijakan dasar dan perintah konstitusi untuk menjamin setiap warga Negara, termasuk orang yang tidak mampu, untuk mendapatkan akses terhadap keadilan agar hak-hak mereka atas pengakuan, jaminan, perlindungan, dan kepastian hukum yang adil serta perlakuan yang sama dihadapan hukum dapat diwujudkan dengan baik. 
Para pengusaha atau wiraswasta, pedagang, UKM, usaha industri rumah tangga dan lain sebagainya untuk mengembangkan usahanya membutuhkan modal yang tidak sedikit. Salah satu cara untuk memenuhi modal tersebut adalah dengan cara mengajukan pinjaman kepada bank yang kemudian dikenal dengan istilah perjanjian kredit bank.

Menurut Kasmir dalam bukunya "Bank dan lembaga keuangan lainnya edisi keenam" menyatakan bahwa :

Adapun yang diartikan dengan "Bank" adalah lembaga keuangan yang kegiatan utamanya adalah menghimpun dana dari masyarakat dalam bentuk simpanan dan menyalurkannya kembali kepada masyarakat dalam bentuk kredit dan/atau dalam bentuk lainnya dalam rangka meningkatkan taraf hidup rakyat banyak. ${ }^{1}$

Ketentuan mengenai perjanjian kredit bank diatur dalam Pasal 1 angka 11 Undang-undang Nomor 10 Tahun 1998 tentang Perbankan, yaitu menyebutkan bahwa:

"Kredit adalah penyediaan uang atau tagihan yang dapat dipersamakan dengan itu, berdasarkan pesetujuan atau kesepakatan pinjammeminjam antara bank dengan pihak lain yang mewajibkan peminjam untuk melunasi hutangnya setelah jangka waktu tertentu dengan pemberian bunga."

Pelaksanaan pemberian kredit kepada debitur, diperlukan suatu keyakinan dari pihak kreditur bahwa kredit yang telah diserahkan kepada debitur dapat dikembalikan sesuai dengan batas waktu yang telah ditentukan dalam perjanjian kredit. Maka sebelum memberikan kredit, kreditur harus melakukan penelitian terhadap watak, kemampuan, modal, agunan, dan prospek usaha debitur. Penelitian yang dilakukan oleh bank ini dimaksudkan untuk menjaga kemungkinan terjadinya tunggakan atau kredit yang bermasalah karena hal ini akan berpengaruh

1 Kasmir, Bank dan Lembaga Keuangan Lainnya Edisi Keenam, Raja Grafindo Persada, Jakarta, 2004, hlm. 11. terhadap kesehatan bank itu sendiri.

Bank sebagai lembaga keuangan banyak diminati oleh masyarakat untuk mengajukan kredit. Mayoritas kegiatan perekonomian di Indonesia menggunakan fasilitas kredit, terutama dunia usaha karena hampir semua dunia usaha membutuhkan kredit untuk menambah modal dan untuk memperluas usahanya serta meningkatkan produktifitas mereka. Kredit yang diberikan oleh bank mengandung resiko, dalam pelaksanaannya harus memperhatikan asasasas perkreditan yang sehat, yaitu:

1. Bank tidak diperkenankan memberikan kredit tanpa surat perjanjian tertulis;

2. Bank tidak diperkenankan memberikan kredit kepada usaha yang sejak semula telah diperhitungkan kurang sehat dan akan memberikan kerugian;

3. Bank tidak diperkenankan memberikan kredit untuk pembelian saham, dan modal kerja dalam rangka kegiatan jual beli saham;

4. Bank tidak diperkenankan memberikan kredit melampaui batas maksimum pemberian kredit (legal lending limit). ${ }^{2}$

Di dalam Pasal 8 Undang-Undang Nomor 10 Tahun 1998 tentang Perbankan menyatakan bahwa:

"Dalam memberikan kredit atau pembiayaan berdasarkan prinsip syariah, Bank Umum wajib mempunyai keyakinan berdasarkan analisis yang mendalam atas itikad dan kemampuan nasabah debitur untuk melunasi utangnya atau mengembalikan pembiayaan dimaksud dengan yang diperjanjikan"

Dari penjelasan pasal tersebut tersirat bahwa jaminan merupakan salah satu faktor dan syarat dalam pertimbangan pemberian kredit. Jaminan atau agunan hanya merupakan salah satu aspek saja, tidak ada kata-kata yang secara tegas menyebutkan keharusan adanya jaminan. Namun demikian, dalam praktik peran jaminan

2 Djumhana Muhammad, Hukum Perbankan Indonesia, Citra Aditya Bakti, Bandung, 2000, hlm. 246. 
sangat menentukan, sebab tanpa jaminan bank tidak berani menanggung risiko tinggi untuk kehilangan dana yang telah disalurkannya. Fungsi dari jaminan antara lain:

1. Untuk menyakinkan bank dalam mengeluarkan kredit;

2. Menjamin agar debitur berperan serta di dalam transaksi untuk membiayai usahanya;

3. Memberikan hak dan kewajiban pada bank untuk mendapatkan pelunasan dari hasil penjualan barang-barang jaminan apabila debitur melakukan cidera janji;

4. Memberikan dorongan kepada debitur untuk memenuhi perjanjian kredit. ${ }^{3}$

Sesuai dengan tujuan dari penelitian ini, penulis lebih menekankan usaha perbankan dalam memberikan kredit dalam bentuk pinjaman modal usaha rumah tangga. Salah satu fasilitas kredit yang tersedia pada PT. Bank Kaltimtara Kantor Cabang Pembantu Samarinda antara lain pemberian Kredit Modal Kerja. Kredit modal adalah salah satu bentuk hutang yang bisa dimanfaatkan. Kepercayaan nasabah pada Bank Kaltimtara merupakan keputusan yang tepat karena Bank Kaltimtara selalu berusaha mendukung kemajuan usaha nasabah pengusaha kecil dan menengah untuk terus mengembangkan bisnis mereka melalui berbagai kredit modal kerja yang sediakan. Pengusaha kecil dan menengah yang sangat banyak jumlahnya di Samarinda sangat potensial bagi perkembangan ekonomi. Pada akhirnya kredit modal kerja yang diberikan kepada pengusaha kecil dan menengah akan menguntungkan kedua belah pihak. Kredit modal kerja yang disediakan oleh PT. Bank Kaltimtara Kantor Cabang Pembantu Samarinda adalah kredit modal kerja secara umum, dealer financing dan distributor financing.

Perjanjian kredit modal kerja merupakan suatu jenis kredit tunai jangka pendek untuk memenuhi kebutuhan modal

3 Chatamarrasjid, Hukum Perbankan Nasional Indonesia, Prenada Media, Jakarta, 2005, hlm. 69-70. kerja, dimana setiap pencairan kreditnya debitur harus memberitahukan kepada bank terlebih dahulu. Dalam perjanjian kredit, para pihak baik itu pihak debitur maupun pihak kreditur sama-sama menghendaki adanya kepastian hukum dalam membuat perjanjian, agar diantara kedua belah pihak baik itu pihak debitur maupun pihak kreditur tidak ada yang diragukan. Maka dibuatlah perjanjian kredit itu secara tertulis oleh para pihak, dan sebagai sumbernya adalah pasal 1233 KUH Perdata yang berbunyi: "Tiap-tiap perikatan dilahirkan baik karena persetujuan, baik karena undang-undang". ${ }^{4}$

Hubungan hukum antara bank dengan nasabah debiturnya berdasarkan hubungan kontraktual atau perjanjian disebut juga dengan perjanjian kredit bank. Walaupun unsur kepercayaan lebih mendominasi pada waktu pemberian kredit, seolah-olah hubungan hukum antara bank dengan nasabah itu hanya berdasarkan kepercayaan. Namun, dalam praktek pemberian kredit, bank tetap mengikat calon nasabahnya dengan perjanjian kredit. Sehingga dapat dikatakan lain, unsur kepercayaan hukum juga mendasari terjadinya hubungan antara bank dengan nasabah. Adapun konsekuensi dari keadaan ini adalah apabila nasabah debitur mengalami kredit macet dan selama unsur pidana tidak ditemukan didalamnya, maka debitur hanya dapat dikatakan wanprestasi dan bukan perbuatan melawan hukum. Jadi, hubungan hukum bank dengan nasabah debitur, bukan hanya hubungan antara kreditur dan debitur berdasarkan kepercayaan dan kontrak saja, tetapi juga sebagai hubungan kerahasiaan dan hubungan kehati-hatian.

\section{B. Rumusan Masalah}

Berdasarkan uraian di atas maka dapat dirumuskan permasalahan yang akan membawa pada pembahasan yang lebih terarah dari penelitian yang dilakukan yaitu :

1. Bagaimana Bentuk Jaminan

${ }^{4}$ Samuel M. P. Hutabarat, Penawaran dan Penerimaan dalam Hukum Perjanjian, Grasindo, Jakarta, 2008, hlm. 33. 
Kepastian Hukum terhadap Pemberian Pinjaman Modal Kegiatan Usaha Rumah Tangga ditinjau dari Undang-Undang Nomor 10 Tahun 1998 Tentang Perubahan atas Undang-Undang Nomor 7 tahun 1992 Tentang Perbankan?

2. Apa Kendala dalam Proses Pinjaman Modal oleh Pelaku Usaha Rumah Tangga di Perbankan?

\section{Tujuan dan Manfaat Penelitian}

Adapun penelitian ini bertujuan untuk mengetahui dan menganalisis Bentuk Jaminan Kepastian Hukum terhadap Pemberian Pinjaman Modal Kegiatan Usaha Rumah Tangga ditinjau dari UndangUndang Nomor 10 Tahun 1998 Tentang Perubahan atas Undang-Undang Nomor 7 tahun 1992 Tentang Perbankan dan untuk mengetahui dan menganalisis Kendala dalam Proses Pinjaman Modal oleh Pelaku Usaha Rumah Tangga di Perbankan.

Penelitian ini diharapkan Menjadi bahan bacaan dan sumber pengetahuan maupun sumber informasi bagi masyarakat umum untuk mengetahui Bentuk Jaminan Kepastian Hukum terhadap Pemberian Pinjaman Modal Kegiatan Usaha Rumah Tangga ditinjau dari Undang-Undang Nomor 10 Tahun 1998 Tentang Perubahan atas Undang-Undang Nomor 7 tahun 1992 Tentang Perbankan, dan juga dapat digunakan sebagai salah satu sumber informasi bagi masyarakat untuk mengetahui Kendala dalam Proses Pinjaman Modal oleh Pelaku Usaha Rumah Tangga di Perbankan.

\section{METODE PENELITIAN}

Jenis Penelitian yang digunakan dalam penelitian ini adalah Hukum Normatif yaitu penelitian yang mempergunakan bahan-bahan kepustakaan sebagai sumber data penelitiannya. ${ }^{5}$ Seperti bahan hukum primer yang meliputi Undang-Undang Republik Indonesia Tahun 1945, Kitab Undang-Undang Hukum

5 Amiruddin dan Zainal Asikin,
Pengantar Metode Penelitian Hukum,
RajaGrafindo Persada, jakarta, 2004, hal. 166

Perdata, Buku II tentang Kebendaan dan Buku III tentang Perikatan, UndangUndang Nomor 10 Tahun 1998 tentang Perubahan atas Undang-Undang Nomor 7 Tahun 1992 tentang Perbankan, UndangUndang Nomor 8 Tahun 1999 tentang Perlindungan Konsumen, Undang-Undang Nomor 24 Tahun 1999 tentang Lalu Lintas Devisa dan Sistem Nilai Tukar, UndangUndang Nomor 40 Tahun 2007 tentang Perseroan Terbatas dan Peraturan Daerah Provinsi Kalimantan Timur Nomor 08 Tahun 2016 tentang Perubahan Bentuk Badan Hukum Bank Pembangunan Daerah Kalimantan Timur dari Perusahaan Daerah Bank Pembangunan Daerah Kalimantan Timur menjadi Perseroan Terbatas Bank Pembangunan Daerah Kalimantan Timur dan Kalimantan Utara.

Bahan Hukum Sekunder yang digunakan guna menunjang bahan hukum primer dengan cara penelitian lapangan yang berhubungan dengan masalah yang diteliti yakni melakukan wawancara kepada sumber terkait, dan bahan hukum tersier yang memberikan petunjuk maupun penjelasan terhadap bahan hukum primer dan bahan hukum sekunder seperti kamus hukum dan kamus bahasa Indonesia.

Metode dan Teknik Pengumpulan data dalam penelitian ini dengan cara Studi Kepustakaan dan Studi Dokumen yaitu dengan cara mempelajari, mengkaji dan mengolah bahan-bahan hukum, baik bahan hukum primer, bahan hukum sekunder maupun bahan hukum tersier, dan teknik wawancara untuk mendapat keterangan guna tujuan penelitian dengan melakukan tanya jawab secara langsung dengan narasumber tentang permasalahan dalam penelitian ini.

Analisis data dalam penelitian ini menggunakan analisis kualitatif yaitu dengan cara mengelompokkan dan menyeleksi data yang diperoleh dari penelitian menurut kualitas dan kebenarannya, kemudian dihubungkan dengan teori-teori dari studi kepustakaan sehingga diperoleh jawaban atas permasalahan dalam penelitian ini. Dalam analisis data ini digunakan cara berfikir 
induktif, yaitu menyimpulkan hasil penelitian dari hal yang bersifat khusus untuk kemudian diambil kesimpulan yang bersifat umum.

\section{PEMBAHASAN}

\section{A. Bentuk Jaminan Kepastian Hukum terhadap Pemberian Pinjaman Modal Kegiatan Usaha Rumah Tangga ditinjau dari Undang-Undang Nomor 10 Tahun 1998 Tentang Perubahan atas Undang-Undang Nomor 7 tahun 1992 Tentang Perbankan.}

Bank tidak bisa begitu saja dengan mudah memberikan kredit/pinjaman modal usaha kepada debitur. Sebelum Bank memberikan pinjaman modal usaha kepada debitur maka terdapat beberapa syarat dan posedur yang harus dipenuhi oleh debitur dalam mengajukan pinjaman modal usaha yakni sebagai berikut :

1. Persyaratan umum dalam mengajukan pinjaman modal usaha antara lain meliputi:

a) Kepemilikan atau pendirian usaha yang telah beroperasi minimal 6 bulan.

b) Usaha debitur harus tergolong UMKM, yakni:

1) Usaha Mikro

2) Usaha Kecil

3) Usaha Menengah

c) Tidak sedang menerima bantuan modal usaha dari perbankan lain.

d) Melengkapi dokumen administrasi seperti :

1) Surat permohonan pengajuan pinjaman modal usaha

2) Surat Izin Usaha atau Surat Keterangan Usaha yang diterbitkan oleh kepala desa / lurah. Biasanya pinjaman dengan plafon di atas 20 juta rupiah (KUR Ritel) harus melampirkan SIUP (Surat Izin Usaha Perdagangan), atau SITU (Surat Izin Tempat Usaha) dan TDP (Tanda Daftar Perusahaan).

Namun, semuanya tergantung kebijakan masing-masing bank penyalur.

3) KTP dan Kartu Keluarga beserta fotocopynya. Bagi usaha yang berbentuk kelompok wajib melampirkan Surat Pengukuhan dari instansi terkait atau Surat Keterangan dari Kepala Desa/ Kelurahan atau Akte Notaris. Lampirkan juga fotocopy KTP masingmasing anggota;

4) Nomor Pokok Wajib Pajak (NPWP). (wajib jika pinjaman lebih dari 50 juta).

5) Surat bukti agunan dan dokumen lain sesuai dengan kebijakan masing-masing bank seperti (BPKB/SKPT/PPAT/SHGB/S HM).

2. Prosedur/Mekanisme Pengajuan Pinjaman Modal Usaha

a. Pemohon mengajukan surat permohonan pinjaman modal usaha kepada Bank dengan melampiri dokumen seperti legalitas usaha (jika ada), perizinan usaha, catatan keuangan dan sebagainya.

b. Bank mengevaluasi/analisa kelayakan usaha berdasarkan permohonan pemohon tersebut.

c. Apabila menurut Bank, usaha pemohon layak maka Bank menyetujui permohonan Pinjaman Modal Usaha tersebut.

d. Bank dan pemohon menandatangani Perjanjian Kredit/Pembiayaan.

e. Pemohon wajib membayar/mengangsur kewajiban pengembalian Pinjaman Modal Usaha tersebut kepada Bank sampai lunas.

Dalam menyalurkan kredit kepada masyarakat untuk kegiatan pembiayaan dan modal usaha, bank diwajibkan menerapkan prinsip kehati-hatian bank (prudential banking principles). hal tersebut didasarkan karena dalam pemberian kredit oleh bank mengandung resiko yang tinggi. Sebelum bank memberikan kredit, hendaknya bank 
menilai dengan seksama prinsip-prinsip sebagai berikut yaitu watak (character), kemampuan (capacity), modal (capital), prospek usaha debitur (condition of economic), dan jaminan (collateral).

Prinsip tersebut sebagai bentuk prinsip kehati-hatian bank. Prinsip Kehatihatian Bank adalah suatu asas atau prinsip yang menyatakan bahwa bank dalam menjalankan fungsi dan kegiatan usahanya wajib bersikap hati-hati (prudent) dalam rangka melindungi dana masyarakat yang dipercayakan padanya. Hal ini disebutkan dalam Pasal 2 Undang-Undang Nomor 10 Tahun 1998 Tentang perubahan atas Undang-Undang Nomor 7 Tahun 1992 Tentang Perbankan, bahwa Perbankan Indonesia dalam melakukan usahanya berasaskan demokrasi ekonomi dengan menggunakan prinsip kehati-hatian. Dimana dengan menggunakan prinsip kehati-hatian akan memberikan rasa nyaman kepada bank itu sendiri dalam menyalurkan dananya kepada debitur.

Adanya jaminan tersebut bagi bank adalah demi keamanan modal dan kepastian hukum bagi bank serta merupakan aspek yang penting dalam pemberian kredit yang dilakukan oleh bank dalam upaya untuk mengamankan atau memberikan jaminan bagi kelancaran pengembalian kredit yang disalurkannya, sedangkan bagi kreditor jaminan tersebut memberikan rasa aman dan kepastian hukum bahwa dana yang dipinjamkan oleh bank dapat dikembalikan tepat waktu sesuai dengan perjanjian.

\section{Bentuk Jaminan terhadap Pemberian Pinjaman Modal Kegiatan Usaha Rumah Tangga.}

Sejatinya, fungsi dari pemberian jaminan adalah guna memberikan hak dan kekuasaan kepada bank untuk mendapatkan pelunasan dengan barang-barang jaminan yang miiliki oleh debitor, bila debitor bercidera janji tidak membayar kembali hutangnya pada waktu yang telah ditetapkan dalam perjanjian maka jaminan tersebut lah yang diambil sebagai gantinya.

Adapun fungsi dari jaminan kredit yakni:

a) Jaminan sebagai pengaman perlunasan kredit; b) Jaminan sebagai pendorong motivasi debitur;

c) Fungsi yang terkait dengan pelaksanaan ketentuan perbankan.

Bank mensyaratkan nasabah menyerahkan jaminan dalam rangka meminimalisir risiko kegagalan debitor dalam pemenuhan kewajibannya kepada bank. Secara yuridis agunan merupakan sesuatu yang sudah pasti dan meyakinkan karena agunan tersebut berupa harta kekayaan milik debitor. Dengan penyerahan harta kekayaan sebagai agunan. Maka dari awal debitor akan menyadari bila usahanya mengalami kegagalan, maka agunan itulah sebagai gantinya.

Sebaliknya jika usaha tersebut berhasil, maka keuntungan yang diperoleh akan jauh lebih besar dibandingkan dengan keuntungan yang diperoleh bank. Dengan demikian agunan merupakan aspek yang penting dalam pemberian kredit yang dilakukan oleh bank dalam upaya untuk mengamankan atau memberikan jaminan bagi kelancaran pengembalian kredit yang disalurkannya.

Ditinjau dari obyek yang dibiayai, maka jaminan dapat dibedakan menjadi jaminan pokok dan jaminan tambahan yang dapat dijelaskan sebagai berikut:

\section{A. Jaminan Pokok}

Jaminan pokok adalah barang atau obyek yang dibiayai dengan kredit. Misalnya seorang nasabah pabrik roti mendapat kredit untuk membeli oven pembakar roti, maka oven pembakar roti tersebut menjadi jaminan pokok. Atau seorang nasabah lain mendapat jaminan untuk pembelian rumah atau yang dikenal dengan KPR, maka jaminan pokok adalah rumah yang dibeli dengan kredit kepemiilikan rumah tersebut. Begitupula apabila ada nasabah lain, yang mendapat pinjaman untuk menambah modal kerja, maka modal kerjanya menjadi jaminan pokok, seperti piutang, persediaan barang dagangan, dll.

\section{B. Jaminan Tambahan}

Jaminan tambahan adalah barang yang dijadikan jaminan untuk menambah 
jaminan pokok. Mengapa jaminan pokok harus ditambah, karena nilainya kurang sebagai akibat penilaian bank lebih rendah dari harganya. Alasannya penilaian bank salah satunya adalah apabila peminjam lalai membayar kewajibannya kepada bank, maka bank mengambilalih jaminan dan dijual. Pada saat menjual tersebut membutuhkan tambahan biaya. Jaminan tambahan yang bernilai tinggi berupa tanah dan bangunan yang telah memiliki sertifikat HM/HGU/HGB dan ber-IMB.

Adapun Bentuk Jaminan jika dilihat dari wujud barang maka bentuk jaminan terbagi menjadi 4 (empat) yakni :

\subsection{Bentuk Jaminan Berwujud}

Jaminan berwujud adalah jaminan tersebut dapat dilihat dan diraba, misalnya oven roti, rumah, mesin, bangunan pabrik, dan kendaraan.

\subsection{Bentuk Jaminan Tidak Berwujud}

Jaminan tidak berwujud adalah jaminan yang bentuknya hanya komitmen atau janji saja. Walaupun demikian janji atau komitmen tersebut harus didokumentasikan ke dalam tulisan, sehingga dapat diadministradikan dengan baik. Contohnya Garansi Perusahaan, Garansi Perorangan.

\subsection{Bentuk Jaminan Benda Bergerak}

Yang dimaksud dengan benda bergerak atau barang bergerak adalah barang yang karena sifatnya dapat berpindah atau dipindahkan. Benda bergerak yang dimaksud dalam hal ini adalah Kendaraan Bermotor seperti mobil dengan berbagai jenis, merek dan tipe serta sepeda motor dan skuter. Hal ini sesuai dengan bunyi Undang-Undang Nomor 14 tahun 1992 tentang lalu lintas dan angkutan jalan raya. Pembuktiannya melalui bukti pemilikan kendaraan bermotor (BPKB).

\subsection{Bentuk Jaminan Benda Tetap / Tidak Bergerak}

Yang dimaksud dengan benda tetap atau barang tidak bergerak adalah suatu benda atau barang yang tidak dapat bergerak atau tidak dapat dipindahkan secara fisik. Benda tetap atau tidak bergerak yang dimaksud antara lain : b) Tanah

Debitur wajib membuktikan kepemilikan tanah tersebut lewat hak milik, hak guna usaha, hak pakai atas tanah negara dan lain-lain.

b) Bangunan

Berupa bangunan seperti rumah tinggal, rumah susun, pabrik, gudang, dan hotel. Nasabah wajib menunjukkan bangunan tersebut sudah dilengkapi IMB (Izin Mendirikan Bangunan) dan status hukumnya apakah sedang ada sengketa atau tidak.

\section{Bentuk Kepastian Hukum terhadap Pemberian Pinjaman Modal Kegiatan Usaha Rumah Tangga \\ Kepastian hukum, pada umumnya} terkait dengan hukum tertulis. Dengan kata lain, hukum tertulis lebih menjamin kepastian hukum dibandingkan dengan hukum tidak tertulis, tetapi hukum tertulis bukanlah satu-satunya sumber hukum. Kepastian hukum perlu diselaraskan dengan tujuan hukum lainnya, antara lain keadilan dan kemanfaatan. Dengan demikian, dalam penerapan hukum tertulis juga perlu diperhatikan hukum yang hidup dan berkembang dalam masyarakat (living law).

Kepastian hukum merupakan perlindungan yustisiabel terhadap tindakan sewenang-wenang, yang berarti bahwa seseorang akan dapat memperoleh sesuatu yang diharapkan dalam keadaan tertentu. Bank mengharapkan adanya kepastian hukum, karena dengan adanya kepastian hukum, Bank akan merasa aman dalam meminjamkan modal kepada debitur.

Adapun bentuk kepastian hukum terhadap pemberian pinjaman modal kegiatan usaha rumah tangga yakni dalam bentuk tertulis yang tertuang didalam Surat Perjanjian Pinjam Uang (SPPU). SPPU mengikuti bentuk perjanjian pada umumnya yang pada dasarnya memuat empat bagian :

a) Bagian pertama yaitu bagian awal/kepala yang memuat judul SPPU dan saat para pihak membuat perjanjian;

b) Bagian kedua adalah bagian koparisi SPPU yaitu bagian dari suatu akta 
yang memuat nama, pekerjaan, alamat bank dan debitur, dasar hukum yang memberikan kewenangan yuridis untuk bertindak dari pihak yang memberi kuasa atau siapa yang diwakili pihak yang bersangkutan serta kedudukan para pihak;

c) Bagian ketiga adalah bagian perjanjian yang memuat persetujuan pendahuluan, kesepakatan kedua belah pihak untuk mengadakan perjanjian kredit;

d) Bagian keempat dari SPPU yaitu bagian isi perjanjian yang memuat klausula-klausula yang diperjanjikan dan memuat tempat dan saat penandatanganan persetujuan pinjaman oleh pihak bank dan debitur.

Menurut hemat penulis untuk menjamin kepastian hukum dalam membuat suatu surat perjanjian pinjaman uang, maka suatu perjanjian itu wajib dibuat dengan memenuhi syarat sahnya perjanjian, sebagaimana yang diatur dalam Pasal 1320 KUHPerdata. Dengan dipenuhinya empat syarat sahnya perjanjian tersebut, maka suatu perjanjian menjadi sah dan mengikat secara hukum bagi para pihak yang membuatnya. Pembuatan perjanjian secara tertulis (kontrak) diperlukan untuk memberikan kepastian hukum bagi para pihak. Sehingga apabila terjadi perselisihan, maka para pihak yang berkepentingan dapat mengajukan perjanjian yang telah dibuat sebagai dasar hukum atau alat bukti untuk menuntut pihak yang telah merugikan.

\section{B. Kendala dalam Proses Pinjaman Modal oleh Pelaku Usaha Rumah Tangga di Perbankan \\ Pada kenyataannya Bank Kaltimtara} sebagai lembaga keuangan komersial daerah kalimantan timur dan kalimantan utara sudah pasti memiliki tujuan mencari keuntungan dari jasa mereka dalam melayani nasabahnya. Untuk itu meski Bank Kaltimtara KCP Mall Lembuswana mendapatkan jatah dana yang tidak sedikit untuk penyaluran dana pinjaman modal usaha/kredit kepada masyarakat, namun standar operasionalnya (SOP) tetap diberlakukan secara profesional dalam melakukan persetujuan kredit. Jadi tidak heran jika dari sekian banyak aplikasi pengajuan pinjaman modal usaha rumah tangga yang diajukan oleh calon debitur terdapat beberapa permohonan yang tidak mendapatkan persetujuan karena terdapat beberapa kendala dalam proses pengajuannya.

Berikut ini merupakan kendalakendala dan masalah yang sering dihadapi oleh calon debitur dalam Proses Pinjaman Modal Usaha Rumah Tangga di Perbankan yakni :

\section{Data Tidak Lengkap dan Valid}

Ketika calon debitur mengajukan aplikasi permohonan pinjaman modal usaha rumah tangga kepada bank, biasanya pihak bank akan meminta calon debitur untuk mengisi form pengajuan kredit. Banyak debitur yang menganggap sepele dengan pengisian formulir ini sehingga mengisinya dengan tidak sungguh-sungguh. Akibatnya data yang ada didalam formulir menjadi tidak lengkap dan valid. Padahal dari data yang diisi dalam formulir tersebut dijadikan acuan oleh bank untuk mengetahui data diri debitur secara jelas dan lebih lengkap.

Oleh karena itu bagi calon debitur yang akan mengisi formulir yang diberikan oleh bank, jujurlah dalam mengisi formulir pinjaman tersebut dan juga teliti semua data dalam formulir tersebut sebelum diserahkan kembali ke pihak bank kalau saja ada isian data atau form yang tidak sesuai atau salah. Bank akan melakukan survey terhadap data yang mereka terima sehingga jika ada data yang tidak valid dan tidak sesuai tentunya bank akan menolak pengajuan aplikasi kredit tersebut.

\section{Prosedur pengajuan pinjaman modal usaha ke bank seringkali memakan waktu, prosesnya berbelit-belit dan syaratnya tidak mudah terpenuhi.}

Saat mengajukan pinjaman modal usaha rumah tangga di bank, banyak pelaku usaha rumah tangga yang merasa proses pengajuan pinjamannya merepotkan. Prosedur pengajuan pinjaman bank bisa memakan waktu berminggu-minggu 
bahkan bisa sampai berbulan- bulan dan bagi debitur untuk memenuhi seluruh persyaratannya tidak selalu mudah. Umumnya, bank mensyaratkan surat-surat usaha atau dokumentasi legal yang tidak dimiliki oleh banyak pemilik usaha rumah tangga karena usaha tersebut tergolong usaha yang kecil.

\section{Usaha Dianggap Kurang Produktif}

Dalam melakukan persetujuan pengajuan pinjaman modal usaha rumah tangga pihak bank akan melakukan verifikasi data dan survey terhadap usaha yang menjadi objek pajak. Dalam melakukan survey tersebut surveyor dibekali kemampuan dalam menilai apakah usaha yang akan dijalankan merupakan usaha yang produktif dengan tingkat kematangan dan peningkatan dimasa mendatang atau justru merupakan usaha yang tidak memiliki prospek cerah dimasa yang akan datang.

Surveyor terkadang juga menanyakan omset bulanan yang bisa diraih dari usaha tersebut sekaligus melakukan perbandingan dengan melihat arus kas yang telah ada. Dengan berpedoman terhadap standar operasional prosedur (SOP) petugas akan memberikan kesan dan pesan terhadap aplikasi kredit yang diajukan apakah layak mendapatkan pinjaman modal atau tidak layak karena alasan tertentu.

\section{Tidak mempunyai Agunan/jaminan tambahan}

Bukan rahasia lagi selain objek yang terdanai sebagai agunan pihak bank juga akan meminta jaminan tambahan baik berupa BPKB Mobil, BPKB Motor, maupun aset berharga lainnya yang dimiliki debitur seperti sertifikat tanah, rumah, ruko, dan lain sebagainya tergantung nominal kredit yang debitur ajukan.

Yang menjadi kendala utama saat ini yakni calon debitur mengira jika mengajukan pinjaman modal usaha rumah tangga dapat diberikan tanpa adanya agunan. Jika melihat prinsip kehati-hatian yang diterapkan oleh bank dalam memberikan pinjaman modal usaha rumah tangga kepada calon debitur maka pastinya bank akan meminta agunan sebagai jaminan jika calon debitur nantinya mengalami kredit macet maka agunan itulah yang dijadikan sebagai pengganti pinjaman yang telah diterima oleh debitur. Oleh karena itulah pihak bank tetap meminta agunan guna menjamin keamanan uang yang mereka pinjamkan kepada debitur agar dapat dikembalikan sebagaimana mestinya.

\section{Legalitas Usaha yang Buruk}

Meski tidak semua jenis usaha dituntut untuk memperlihatkan surat ijin usaha namun jika legalitas usaha yang calon debitur ajukan sebagai objek pinjaman/kredit dirasa meragukan maka petugas bank akan lebih berhati-hati dalam memberikan persetujuan. Terlebih lagi jika kepemilikan usaha tersebut tidak jelas misalnya milik kelompok atau rombongan.

Untuk dapat memastikan permohonan pinjaman modal usaha rumah tangga calon debitur agar mendapatkan persetujuan oleh bank, tidak ada salahnya jika calon debitur melengkapi surat ijin usaha sah sebagaimana yang menjadi persyaratan dalam pengajuan pinjaman.

\section{Riwayat Kredit Buruk}

Permasalan sepele namun fatal ini menjadi kendala yang tak dapat terelakan bagi sebagian calon debitur dalam mengajukan pinjaman modal usaha rumah tangga baik melalui Bank Kaltimtara, BRI, Mandiri, BNI maupun bank lainnya. Jika calon debitur pernah mengalami permasalah kredit macet baik dari pinjaman konsumtif maupun produktif maka kemungkinan permohonan tersebut disetujui sangat kecil. Pasalnya dalam melakukan verifikasi data pihak bank akan melihat rekam jejak calon debitur didunia perbankan melalui Sistem Informasi Debitur. Untuk itu sebelum mengajukan pinjaman modal usaha rumah tangga debitur setidaknya tidak memiliki riwayat kredit macet atau permasalahan lain yang berkaitan dengan perbankan agar proses permohonan pinjaman modal usaha tersebut tidak terkendala karena riwayat kredit yang buruk. 
Kendala-kendala tersebut di atas lah yang membuat pelaku usaha rumah tangga sering kesulitan mendapatkan pinjaman bank untuk mengembangkan usaha mereka. Hal ini tentunya menjadi tantangan bagi pelaku usaha rumah tangga itu sendiri dalam menghadapi setiap kendala dalam proses pinjaman modal usaha rumah tangga di PT. Bankaltimtara KCP Mall Lembuswana.

\section{PENUTUP KESIMPULAN DAN SARAN}

Adapun kesimpulan dalam penelitian ini yaitu bahwa Bentuk Jaminan Kepastian Hukum terhadap Pemberian Pinjaman Modal Kegiatan Usaha Rumah Tangga ditinjau dari Undang-Undang Nomor 10 Tahun 1998 Tentang Perubahan atas Undang-Undang Nomor 7 tahun 1992 Tentang Perbankan yakni Adapun Bentuk Jaminan jika dilihat dari wujud barang maka bentuk jaminan terbagi menjadi 4 (empat) yakni Bentuk Jaminan Berwujud, Bentuk Jaminan Tidak Berwujud, Bentuk Jaminan Benda Bergerak, Bentuk Jaminan Benda Tetap / Tidak Bergerak. Dan Adapun bentuk kepastian hukum terhadap pemberian pinjaman modal kegiatan usaha rumah tangga yakni dalam bentuk tertulis yang tertuang didalam Surat Perjanjian Pinjam Uang (SPPU).

Kendala dalam Proses Pinjaman Modal oleh Pelaku Usaha Rumah Tangga di Perbankan yakni Data Tidak Lengkap dan Valid, Prosedur pengajuan pinjaman modal usaha ke bank seringkali memakan waktu, prosesnya berbelit-belit dan syaratnya tidak mudah terpenuhi, Usaha Dianggap Kurang Produktif, Tidak adanya Agunan/Jaminan Tambahan, Legalitas Usaha yang dianggap buruk, Riwayat Kredit Buruk.

Adapun Saran dalam penelitian ini Diharapkan dengan adanya jaminan kepastian hukum yang diterapkan oleh pihak perbankan dapat selalu memberikan rasa aman kepada bank itu sendiri dalam menyalurkan dananya kepada masyarakat, dan diharapkan juga dapat selalu memberikan rasa nyaman kepada masyarakat dalam hal pinjaman modal usaha agar usaha masyarakat dapat berjalan dengan baik lagi.

Hendaknya bank dalam memberikan kredit lebih menekankan kepada kelayakan usaha calon nasabah daripada menekankan pada tersedianya jaminan, sehingga mereka yang benar-benar membutuhkan modal dengan prospek usaha yang baik dan mempunyai kesanggupan untuk mengembalikkan kredit sesuai dengan syarat-syarat yang di tentukan dan diharapkan bagi para calon debitur yang ingin mengajukan pinjaman modal usaha rumah tangga, sebaiknya terlebih dahulu dapat mengikuti segala prosedur yang telah ditetapkan oleh bank dengan sebaikbaiknya dan mengisi data dengan sebenarbenarnya, serta setidak nya memiliki agunan yang dapat dijaminkan, kemudian tidak mempunyai riwayat kredit yang buruk dan tidak mengajukan dana pinjaman yang tidak masuk akal. 


\section{DAFTAR PUSTAKA}

\section{Daftar Buku :}

Abdul Ghofur Anshori, perjanjian islam dalam Indonesia, konsep gegulasi dan implementasi, yokyakarta, 2010.

Achmad Ali, Menguak Tabir Hukum (Suatu Kajian Filosofis dan Sosiologis), Gunung Agung, Jakarta, 2002.

Amiruddin dan Zainal Asikin, Pengantar Metode Penelitian Hukum, RajaGrafindo Persada, jakarta, 2004.

Bahsan, M. Penilaian Jaminan Kredit Perbankan Indonesia, Rejeki Agung, Jakarta, 2002.

Bukhari Alma, Dasar-Dasar Etika Bisnis Islami, Alfabeta, Bandung, 2003.

Chatamarrasjid, Hukum Perbankan Nasional Indonesia, Prenada Media, Jakarta, 2005.

Djumhana Muhammad, Hukum Perbankan Indonesia, Citra Aditya Bakti, Bandung, 2000.

Gatot Supramono, Perbankan dan Masalah Kredit, Djambatan, Jakarta, 2005.

Hartono Hadisoeprapto, Hukum Jaminan, Raja Grafindo Persada, Jakarta, 2001.

Mariam Darus Badrulzaman, Hukum Perdata Tentang perikatan, Citra Aditya Bakti, Bandung, 2001.

Marhainis Abdul Hay, Hukum Perbankan Di Indonesia, Pradnya Paramita, Jakarta, 2006.
Rachmadi Usman, Aspek-Aspek Hukum Perbankan di Indonesia, Gramedia Pustaka Utama, Jakarta, 2001.

Riduan Syahrani, Rangkuman Intisari Ilmu Hukum, Citra Aditya Bakti, Bandung, 2003.

R. Setiawan, Pokok Hukum Perikatan, Bina Cipta, Bandung, 2002.

R. Subekti, Hukum Pinjaman, Pradnya Paramita, Jakarta , 2003.

Samuel M. P. Hutabarat, Penawaran dan Penerimaan dalam Hukum Perjanjian, Grasindo, Jakarta, 2008.

Salim HS, H, S.H., M.S, Perkembangan Hukum Jaminan di Indonesia, Raja Grafindo Persada, Jakarta, 2011.

Sembiring, Sentosa, Hukum Perbankan, Mandar Maju, Bandung, 2008.

Peraturan Perundang-undangan :

Undang-Undang RI Dasar 1945

Kitab Undang-Undang Hukum Perdata, Buku II tentang Kebendaan dan Buku II tentang Perikatan.

Undang-Undang Nomor 10 Tahun 1998 Tentang Perubahan atas Undang-Undang Nomor 7 tahun 1992 Tentang Perbankan

Undang-Undang Nomor 8 Tahun 1999 tentang Perlindungan Konsumen. 
Undang-Undang Nomor 24 Tahun 1999 tentang Lalu Lintas Devisa dan Sistem Nilai Tukar.
Undang-Undang Nomor 40 Tahun 2007 tentang Perseroan Terbatas.

Peraturan Daerah Provinsi Kalimantan Timur Nomor 08 Tahun 2016 tentang Perubahan Bentuk Badan Hukum Bank Pembangunan Daerah Kalimantan Timur dari Perusahaan Daerah Bank Pembangunan Daerah Kalimantan Timur menjadi Perseroan Terbatas Bank Pembangunan Daerah Kalimantan Timur dan Kalimantan Utara.

\section{Internet :}

https://bankaltimtara.co.id/id/page/ten tang-bankaltimtara, diakses pada tanggal 21 Juli 2018. 